Article

\title{
Energy Efficiency and Sustainability Evaluation of Space and Water Heating in Urban Residential Buildings of the Hot Summer and Cold Winter Zone in China
}

\author{
Xiao Chen ${ }^{1,2}, *$, Yongquan Wen ${ }^{2}$ and Nanyang $\mathrm{Li}^{2}$ \\ 1 Hunan Provincial Key Laboratory of Wind Generator and Its Control, Hunan Institute of Engineering, \\ Xiangtan 411104, China \\ 2 School of Architectural Engineering, Hunan Institute of Engineering, Xiangtan 411104, China; \\ m13347222966@163.com (Y.W.); m15773236695_1@163.com (N.L.) \\ * Correspondence: hsiaochen@hnie.edu.cn; Tel.: +86-731-5868-0204
}

Academic Editor: Umberto Berardi

Received: 5 July 2016; Accepted: 27 September 2016; Published: 30 September 2016

\begin{abstract}
With the urbanization process of the hot summer and cold winter (HSCW) zone in China, the energy consumption of space and water heating in urban residential buildings of the HSCW zone has increased rapidly. This study presents the energy efficiency and sustainability evaluation of various ways of space and water heating taking 10 typical cities in the HSCW zone as research cases. Two indicators, primary energy efficiency (PEE) and sustainability index based on exergy efficiency, are adopted to perform the evaluation. Models for the energy and total exergy efficiencies of various space and water heating equipment/systems are developed. The evaluation results indicate that common uses of electricity for space and water heating are the most unsustainable ways of space and water heating. In terms of PEE and sustainability index, air-source heat pumps for space and water heating are suitable for the HSCW zone. The PEE and sustainability index of solar water heaters with auxiliary electric heaters are greatly influenced by local solar resources. Air-source heat pump assisted solar hot water systems are the most sustainable among all water heating equipment/systems investigated in this study. Our works suggest the key potential for improving the energy efficiency and the sustainability of space and water heating in urban residential buildings of the HSCW zone.
\end{abstract}

Keywords: primary energy efficiency; sustainability index; exergy analysis; urban residential buildings; hot summer and cold winter zone

\section{Introduction}

Energy plays an essential role for economic growth and improvement of life quality. In a sense, the building energy proportion of the total energy consumption is a barometer of the domestic economy of a country. In 2009, the building sector in China was responsible for $20 \%$ of China's total primary energy consumption and $18 \%$ of the overall Chinese greenhouse gas emissions [1]. The ratio of permanent urban residents to total population (urbanization rate) of China had reached $56.1 \%$ by the end of 2015 [2]. With the improvement of the living standards of urban residents, the energy consumption in residential buildings has increased considerably during these last few years. The evaluation of energy efficiency and energy consumption has become the sustainability measure for building assessment [3].

Exergy is defined as the maximum amount of work which can be produced by a system or a flow of matter or energy when it comes to equilibrium with a specified reference environment [4]. The exergy of an energy form or a substance is a measure of its usefulness or quality, and thus is a measure of its potential to cause change [5,6]. Unlike energy, exergy is conserved only during 
ideal processes and destroyed due to irreversibilities in real processes [7]. Exergy analysis is based on the first and second laws of thermodynamics, and can be used to identify the main sources of irreversibility (exergy loss) [4,8]. Exergy analysis is widely used for estimation of how near a process is to "thermodynamic ideality", and has become an effective tool for engineers to reveal the potential to improve energy efficiency by reducing the inefficiencies in energy systems $[9,10]$. Sustainable development requires energy resources to be used efficiently [7]. Exergy analysis is essential in improving energy efficiency and can be used to obtain sustainable development $[7,11]$. Exergy efficiency is identified as an indicator affecting sustainability [11]. Sustainability of a process will increase as the exergy efficiency of the process increases [7].

Exergy analysis has been applied to evaluate the energy utilization efficiency in residential buildings of various countries [12-18]. Utlu and Hepbasli evaluated the energy utilization efficiency in the Turkish residential-commercial sector using energy and exergy analysis [12,13]. Dincer et al. presented the analysis of energy and exergy utilization in various sectors, including the residential sector, of Saudi Arabia [14]. Similarly, the analyses of energy and exergy use of the residential sector of Jordan, Malaysia and Cameroon were conducted [15-17]. Liu et al. evaluated the overall energy and exergy efficiencies in the urban residential sector of China using simplified models [18]. Like previous researchers in References [12-17], Liu et al. simplified the variable temperature refrigeration/heat pump cycle as a constant temperature cycle between indoor temperature and outdoor temperature. The thermodynamics mechanism of the water heating process in Reference [18] was identified with that of the space heating process, which led to approximate models and results. The energy and exergy efficiencies of renewable energy utilization were not evaluated in Reference [18].

Previous works mainly focused on evaluating the overall energy and exergy efficiencies of a country's residential sector [12-18]. Due to China's vast geographic area, the weather conditions and the ways of space and water heating vary from region to region. Since 1993, the whole geographic area of China has been divided into five zones in terms of weather conditions: the hot summer and cold winter (HSCW) zone, the hot summer and warm winter zone, the cold zone, the severe cold zone and the mild zone [19]. The overall exergy efficiency in the urban residential sector of China based on approximate models in Reference [18] are only for general reference, and can not really reflect the exergy efficiency in urban residential buildings of different regions in China. This paper aims to evaluate the energy efficiency, exergy efficiency and sustainabilities of present space and water heating equipment/systems in urban residential buildings of the HSCW zone using more reasonable models. The reasons for low exergy efficiencies of some energy-use processes are discussed.

\section{Description of the HSCW Zone in China}

The HSCW zone mainly consists of the Middle-Lower Yangtze River area, which is about 1.8 million $\mathrm{km}^{2}$ in area. The HSCW zone is a vital region with a population of 0.55 billion and a prosperous economy. The GDP of the HSCW zone makes up about $48 \%$ of China's total GDP [20].

The climatic characteristics of the HSCW zone can be seen from the average outdoor temperature (AOT) and relative humidity (RH) of different cities in summer and winter. Table 1 shows the statistics based on the meteorological data (from 1971 to 2003) of 10 typical cities in different regions of the HSCW zone [21]. These cities have a typical climate characterized by hot summers and cold, damp winters. The AOTs in the hottest month are no lower than $28^{\circ} \mathrm{C}$ except Chengdu, and the AOTs in the heating season (from December to February, totaling 90 days) of these cities averaged $6{ }^{\circ} \mathrm{C}$. The average $\mathrm{RH}$ values in the coldest month range from $75 \%$ to $83 \%$. In winter, high humidity leads to a more intense feeling of cold even though the outdoor temperature is not very low.

The climatic features of the HSCW zone bring huge energy demands for space heating and cooling in residential buildings. Domestic hot water is needed almost everyday in a residence for bathing, washing and other sanitary purposes, and is associated with a significant proportion of energy consumption in residential buildings. From 2001 to 2011, the energy consumptions of space cooling, space heating and water heating in urban residential buildings of the HSCW zone increased by 5.4, 
4.4 and 1.8 times, respectively [22]. In 2011, the electricity consumption of space heating in urban residential buildings of the HSCW zone reached 41.4 billion $\mathrm{kWh}$ [22].

Table 1. Statistics based on the meteorological data (from 1971 to 2003) of 10 cities in the HSCW zone [21].

\begin{tabular}{cccc}
\hline City & $\begin{array}{c}\text { AOT in the Hottest } \\
\text { Month }\left({ }^{\circ} \mathbf{C}\right)\end{array}$ & $\begin{array}{r}\text { AOT in Heating } \\
\text { Season }\left({ }^{\circ} \mathbf{C}\right)\end{array}$ & $\begin{array}{c}\text { Average RH in the } \\
\text { Coldest Month (\%) }\end{array}$ \\
\hline Chongqing & 28.6 & 8.9 & 83 \\
Chengdu & 25.8 & 7.1 & 83 \\
Wuhan & 28.7 & 5.5 & 77 \\
Changsha & 29.3 & 6.2 & 83 \\
Hangzhou & 28.5 & 5.6 & 76 \\
Nanchang & 29.5 & 6.9 & 77 \\
Shanghai & 28.2 & 5.4 & 75 \\
Nanjing & 28.0 & 4.3 & 76 \\
Hefei & 28.2 & 4.4 & 76 \\
Ningbo & 28.3 & 5.8 & 79 \\
\hline
\end{tabular}

\section{Ways of Space and Water Heating in Urban Residential Buildings of the HSCW Zone}

About 0.3 billion people live in urban areas of the HSCW zone, and consume enormous energy in residential buildings. The energy-consuming equipments in urban residential buildings of the HSCW zone can be classified into six categories: room air conditioners, space heating equipments, water heating equipments, lamps, cookers and other household electrical appliances. The demands for space cooling, lighting, cooking, laundry, television, etc. are, respectively, implemented by a certain kind of equipment. However, the demands for space and water heating in urban residential buildings of the HSCW zone can be respectively implemented by several kinds of equipments.

In the cold zone and severe cold zone of China, extensive district heating systems have been constructed in urban areas. From the viewpoint of saving energy and initial cost, no extensive district heating system was constructed in the HSCW zone because the total days in which daily AOT was below $5{ }^{\circ} \mathrm{C}$ during a year were less than 90 according to the meteorological statistics. In urban areas of the HSCW zone, the use of coal-fired boilers for space and water heating is mostly forbidden to reduce the discharge of urban pollutants. The houses in the HSCW zone are commonly equipped with split type room air conditioners, which operate as air-source heat pumps in winter. Many households use electric space heating equipments to heat local space of a room. Four types of electric space heating equipments used in urban residential buildings of the HSCW zone are shown in Figure 1. In addition, some houses are equipped with gas furnaces that are connected with radiant floors or radiators. The thermal comfort condition can be improved by using radiant floors or radiators, though the initial cost and operating cost of such systems are relatively high.
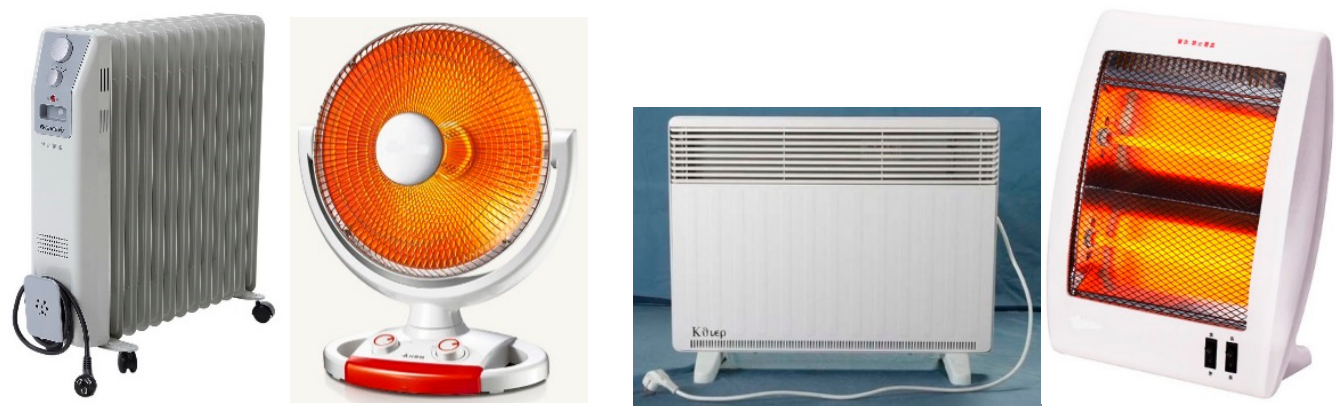

Figure 1. Four types of electric space heating equipments used in urban residential buildings of the HSCW zone. 
The water heating equipments used in urban residential buildings of the HSCW zone are various as well. Table 2 shows the analyses of domestic water heater sales and possession rates in 2014 . According to the proportion of sales and the results of surveys for possession rates in China [23,24], electric water heaters (EWHs), gas water heaters (GWHs) and solar water heaters (SWHs) were in the top three in 2014. The market share and possession rate of air-source heat pump (ASHP) water heaters all were only $3 \%$. The utilizations of solar energy in urban residential buildings of the HSCW zone are mostly decentralized as the solar water heaters in Figure 2. The solar water heaters with evacuated tube solar collectors are more popular than those with flat plate solar collectors. From the viewpoint of controlling initial cost of domestic solar water heaters, electric heaters are mostly used to provide auxiliary heat for hot water production when solar radiation is insufficient. There are some ASHP assisted solar hot water systems in urban residential buildings of the HSCW zone, most of which are centralized systems for multi-family buildings.

Table 2. Breakdown of domestic water heater sales and possession rate in 2014 [23,24].

\begin{tabular}{cccc}
\hline & Sales (Units) & $\begin{array}{c}\text { Proportion of } \\
\text { Sales (\%) }\end{array}$ & $\begin{array}{c}\text { Possession } \\
\text { Rate (\%) }\end{array}$ \\
\hline Electric water heaters & $15,200,000$ & 40 & 42 \\
Gas water heaters & $12,160,000$ & 32 & 35 \\
Solar water heaters & $9,500,000$ & 25 & 20 \\
Air-source heat pump water heaters & $1,106,000$ & 3 & 3 \\
Totals & $37,966,000$ & 100 & 100 \\
\hline
\end{tabular}

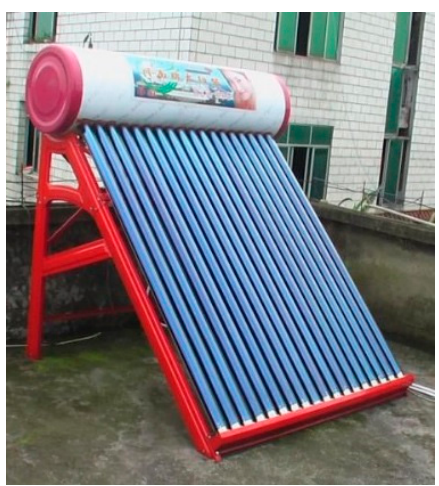

(a)

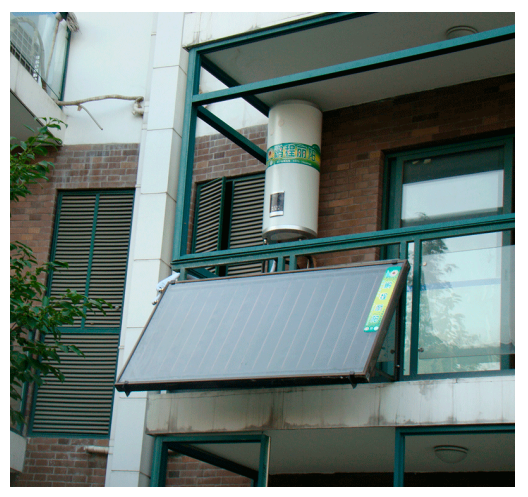

(b)

Figure 2. Decentralized solar water heaters with: (a) evacuated tube solar collectors; (b) flat plate solar collectors.

The aforementioned space and water heating equipment/systems utilize different energy forms as energy input. Therefore, it is more reasonable using exergy efficiency other than energy efficiency to evaluate the thermodynamic perfectibility of the aforementioned equipment/systems and the rationality of energy utilization.

\section{Methodology}

\subsection{Definitions of the Indicators in This Study}

The energy efficiency $(\eta)$ for the commercial energy utilization of an equipment/system is expressed as

$$
\eta=\frac{Q_{u}}{E_{i n}}
$$

where $Q_{u}$ is useful heat production, and $E_{i n}$ is commercial energy input. For the space and water heating equipment/systems with electricity as energy input, energy efficiency can not reflect the 
primary energy utilization efficiency. In this study, primary energy efficiency (PEE) is used to evaluate the overall efficiency of an equipment/system and relevant energy supply system, which can be calculated by

$$
P E E=\eta \times \beta \times(1-\alpha),
$$

where $\beta$ is thermal power generation efficiency, and $\alpha$ is electric grid loss ratio.

The total exergy efficiency $(\Psi)$ of an equipment/system and relevant energy supply system is expressed as below:

$$
\psi=\frac{E X_{\text {out }}}{E X_{\text {in }}}
$$

where $E X_{\text {out }}$ is exergy production, and $E X_{\text {in }}$ is the exergy input from primary energy. The chemical exergy of natural gas is calculated by [25]

$$
E X_{g a s}=0.95 \times \theta_{H}
$$

where $E X_{g a s}$ and $\theta_{H}$ are, respectively, the chemical exergy and higher heating value of natural gas $(\mathrm{kJ} / \mathrm{kg})$. The chemical exergy of the coal for thermal power generation is calculated by [25]

$$
E X_{\text {coal }}=1.03 \times \theta_{L}
$$

where $E X_{\text {coal }}$ and $\theta_{L}$ are, respectively, the chemical exergy and lower heating value of the coal for thermal power generation $(\mathrm{kJ} / \mathrm{kg})$.

The sustainability index (SI) of an equipment/system is only related to its exergy efficiency, and is expressed as [7]

$$
S I=\frac{1}{1-\psi} .
$$

\subsection{Models for the Energy and Exergy Efficiencies of Space Heating Equipments}

\subsubsection{Air-Source Heat Pumps}

The heat pump cycle can be regarded as an equivalent reverse Carnot cycle, which is equivalent to a Lorenz cycle with a variable-temperature heat source and sink. The heat source and sink temperatures of the equivalent reverse Carnot cycle are considered to be equal to the average air temperatures in the evaporator and the condenser of an ASHP, respectively. Therefore, the total exergy efficiency of ASHPs is calculated from the following equation:

$$
\psi=\frac{P E E_{a}}{1.03}\left[1-\left(\frac{T_{1, \text { in }}+T_{1, \text { out }}}{T_{2, \text { in }}+T_{2, \text { out }}}\right)\right]
$$

where $P E E_{a}$ is the PEE of ASHPs, $T_{1, \text { in }}$ and $T_{1, \text { out }}$ are, respectively, the entering and leaving air temperatures of outdoor units (evaporators) (K), and $T_{2, i n}$ and $T_{2, o u t}$ are, respectively, the entering and leaving air temperatures of indoor units (condensers) (K). The energy efficiency of a room air conditioner in heating season is equal to its heating seasonal performance factor (HSPF).

\subsubsection{Electric Space Heating Equipments}

The total exergy efficiency of electric space heating equipments is calculated by

$$
\psi=\frac{P E E_{e h}}{1.03}\left[1-\left(\frac{T_{0}}{T_{N}}\right)\right]
$$

where $P E E_{e h}$ is the PEE of electric space heating equipments, $T_{N}$ is indoor temperature $(\mathrm{K})$, and $T_{0}$ is reference temperature $(\mathrm{K})$. 


\subsubsection{Gas Furnaces}

The exergy efficiency of gas furnaces for space heating is calculated from the equation

$$
\psi=\left(\frac{\eta_{h}}{0.95}\right)\left[1-\frac{T_{0}}{T_{s}-T_{r}} \ln \left(\frac{T_{s}}{T_{r}}\right)\right]
$$

where $T_{s}$ is supply water temperature $(\mathrm{K}), T_{r}$ is return water temperature $(\mathrm{K})$, and $\eta_{h}$ is the thermal efficiency based on higher heating value of natural gas. The supply and return water temperatures of radiators are higher than those of radiant floors.

\subsection{Models for the Energy and Exergy Efficiencies of Water Heating Equipment/Systems}

\subsubsection{Electric Water Heaters}

For the households with no gas supply, the use of EWHs is one of the top choices. Thus, EWHs have become the most popular water heaters in China $[23,24]$. The energy efficiency of storage EWHs, the most commonly used EWHs, is lower than that of instant EWHs due to the heat loss of hot water tank. The total exergy efficiency of EWHs is calculated by

$$
\psi=\frac{P E E_{e w}}{1.03}\left[1-\frac{T_{0}}{T_{h}-T_{c}} \ln \left(\frac{T_{h}}{T_{c}}\right)\right],
$$

where $P E E_{\text {ew }}$ is the PEE of electric water heaters, $T_{c}$ is cold water temperature $(\mathrm{K})$, and $T_{h}$ is hot water temperature (K).

\subsubsection{Gas Water Heaters}

The exergy efficiency of GWHs can be calculated by

$$
\psi=\left(\frac{\eta_{h}}{0.95}\right)\left[1-\frac{T_{0}}{T_{h}-T_{c}} \ln \left(\frac{T_{h}}{T_{c}}\right)\right] .
$$

\subsubsection{Solar Water Heaters with Auxiliary Electric Heaters}

Auxiliary electric heaters are commonly used in decentralized solar water heaters to make up for the insufficiency of solar radiation. Considering the electricity consumption of auxiliary electric heaters as commercial energy input, we can derive the equations for calculating the energy and total exergy efficiencies of SWHs as follows

$$
\begin{gathered}
\eta=\frac{\lambda(1-R)}{1-f_{a}}, \\
\psi=\frac{P E E_{s o}}{1.03}\left[1-\frac{T_{0}}{T_{h}-T_{c}} \ln \left(\frac{T_{h}}{T_{c}}\right)\right],
\end{gathered}
$$

where $P E E_{s o}$ is the PEE of SWHs with auxiliary electric heaters, $\lambda$ is the energy efficiency of electric heaters, and taken as $90 \%$; and $f_{a}$ is the annual average solar fraction, and is equal to an average value of daily solar fractions during a year. The daily solar fraction of a day is calculated by

$$
f_{d}=\frac{I_{T} A \phi(1-R)}{\rho V C\left(T_{h}-T_{d}\right)}
$$

where $f_{d}$ is daily solar fraction, $A$ is solar collector area $\left(\mathrm{m}^{2}\right), \phi$ is annual average efficiency of solar collector, $\varrho$ is water density $\left(\mathrm{kg} / \mathrm{m}^{3}\right), V$ is daily hot water consumption $\left(\mathrm{m}^{3} / \mathrm{d}\right), C$ is specific heat of water $(\mathrm{kJ} / \mathrm{kg} \cdot \mathrm{K}), I_{T}$ is daily solar radiation on the tilted surface facing south at a tilt angle equal to local latitude $\left(\mathrm{kJ} / \mathrm{m}^{2} \cdot \mathrm{d}\right)$, and $T_{d}$ is daily average cold water temperature and equal to $5{ }^{\circ} \mathrm{C}$ when daily AOT 
is below $5{ }^{\circ} \mathrm{C}$. When daily AOT is no lower than $5{ }^{\circ} \mathrm{C}, T_{d}$ is assumed to be equal to daily AOT. $R$ is the heat loss rate of hot water tank and pipe.

\subsubsection{ASHP Water Heaters}

ASHP water heaters can utilize low-grade and renewable heat from ambient air on the basis of consuming a certain amount of electric energy. The energy and total exergy efficiencies of ASHP water heaters can be calculated in terms of its annual average coefficient of performance $(C O P)$ as follows:

$$
\begin{gathered}
\eta=\operatorname{COP}_{a n n}(1-R), \\
\psi=\frac{P E E_{a w w}}{1.03}\left[1-\frac{T_{0}}{T_{h}-T_{c}} \ln \left(\frac{T_{h}}{T_{c}}\right)\right],
\end{gathered}
$$

where $C O P_{a n n}$ is the annual average COP, and $P E E_{a w}$ is the PEE of ASHP water heaters. In this study, the COP values of an ASHP water heater at various outdoor temperatures were measured, and the measurement results are illustrated in Figure 3. The COP values are generally linearly related to outdoor temperatures. According to the fitting formula shown in Figure 3, the annual average COP can be calculated by

$$
\mathrm{COP}_{\text {ann }}=\frac{1}{365} \sum_{i=1}^{365}\left(0.105 A O T_{i}+1.636\right),
$$

where $A O T_{i}$ is the AOT of the $i$ th day during a year.

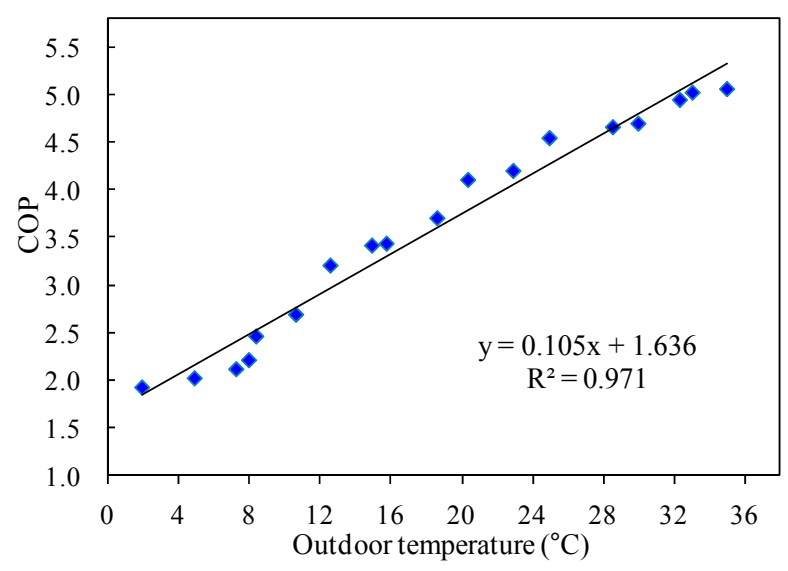

Figure 3. The COP values of an ASHP water heater at various outdoor temperatures.

\subsubsection{ASHP Assisted Solar Hot Water Systems}

In ASHP assisted solar hot water systems, ASHPs are used to provide auxiliary heat when solar radiation is insufficient. The energy and total exergy efficiencies of ASHP assisted solar hot water systems can be calculated by

$$
\begin{gathered}
\eta=\frac{\operatorname{COP}_{a u x}(1-R)}{1-f_{a}}, \\
\psi=\frac{P E E_{a s}}{1.03}\left[1-\frac{T_{0}}{T_{h}-T_{c}} \ln \left(\frac{T_{h}}{T_{c}}\right)\right],
\end{gathered}
$$

where $C O P_{a u x}$ is the average COP of the ASHPs for auxiliary heating, and $P E E_{a s}$ is the PEE of ASHP assisted solar hot water systems. The ASHPs in such systems mostly operate on relative cold days to make up for insufficient solar radiation. In this study, $\mathrm{COP}_{\text {aux }}$ is taken as the average COP of an ASHP during the period from November to March. 


\section{Results and Discussion}

\subsection{Determination of Parameters}

To calculate the two efficiencies, the parameters in Equations (7)-(19) are determined. The reference temperature for the calculation about space heating is taken to be equal to the average value of AOTs in heating season in Table $1\left(T_{0}=6^{\circ} \mathrm{C}\right)$. The coal-fired thermal power generation efficiency in China has been gradually increased in recent years. The average coal-fired thermal power generation efficiency and electric grid loss ratio in China are taken to be $39.8 \%$ and $6.4 \%$, respectively [26]. The other parameter values for space heating equipment are listed in Table 4.

The reference temperatures for the calculation about water heating are equal to the annual AOTs of the 10 typical cities and shown in Table 3. In view of the fact that the cold water temperature in the HSCW zone is close to the outdoor temperature, it is assumed that $T_{c}$ is equal to annual AOT. $T_{h}$ is taken to be $45^{\circ} \mathrm{C}$, which is a little higher than the hot water temperature for practical usage in households. Daily solar radiation and daily AOT are taken from Typical Meteorological Year (TMY) weather data of the 10 cities [21]. According to the common device configuration of domestic SWHs in the Chinese market, we take a domestic SWH with a collector area of $4 \mathrm{~m}^{2}$ and a production of $300 \mathrm{~L}$ hot water volume per day as calculation case. A small ASHP assisted solar hot water system with the same collector area and hot water production is adopted as the calculation case. The annual average efficiency of the solar collectors is $60 \%$, and the heat loss rate of a hot water tank and pipe is taken as $15 \%$. The COP values, annual average solar fraction and $I_{T}$ in the 10 typical cities are determined and shown in Table 3. The average thermal efficiency of GWHs and gas furnaces based on higher heating value of natural gas is taken to be $80 \%$. The average energy efficiencies of storage EWHs and instant EWHs are taken to be $75 \%$ and $90 \%$, respectively.

Table 3. Average values for efficiency evaluation of solar and ASHP water heaters.

\begin{tabular}{|c|c|c|c|c|c|}
\hline City & Annual Average $I_{T}\left(\mathrm{~kJ} / \mathrm{m}^{2} \cdot \mathrm{d}\right)$ & $f_{a}(\%)$ & $T_{0}\left({ }^{\circ} \mathrm{C}\right)$ & $C O P_{a n n}$ & $\mathrm{COP}_{\text {aux }}$ \\
\hline Chongqing & 8552 & 54.6 & 17.7 & 3.55 & 2.77 \\
\hline Chengdu & 9305 & 62.3 & 16.1 & 3.36 & 2.55 \\
\hline Wuhan & 11,869 & 69.5 & 16.6 & 3.43 & 2.63 \\
\hline Changsha & 11,061 & 65.5 & 17.0 & 3.46 & 2.69 \\
\hline Hangzhou & 11,621 & 69.0 & 16.5 & 3.43 & 2.58 \\
\hline Nanchang & 12,158 & 70.9 & 17.6 & 3.50 & 2.73 \\
\hline Shanghai & 13,447 & 76.5 & 16.1 & 3.40 & 2.53 \\
\hline Nanjing & 13,960 & 76.9 & 15.5 & 3.29 & 2.49 \\
\hline Hefei & 13,240 & 75.6 & 15.8 & 3.35 & 2.51 \\
\hline Ningbo & 12,721 & 74.0 & 16.5 & 3.42 & 2.62 \\
\hline
\end{tabular}

\subsection{Calculation Results for Space Heating and Discussion}

The calculation results of space heating equipments are shown in Table 4. Electric space heating is the most unsustainable way for space heating due to its lowest PEE (36.51\%), exergy efficiency $(1.46 \%)$ and sustainability index (1.015), though its energy efficiency is higher than that of gas furnaces. The result of comparison between the energy efficiencies of electric heating and gas furnaces is misleading. The exergy efficiency of the gas furnaces with radiators is higher than that of the gas furnaces with radiant floors because the higher supply temperature of radiators brings more thermal exergy production. Considering that the share of gas furnaces with radiators is close to that of gas furnaces with radiant floors, the average exergy efficiency of gas furnaces is around $12 \%$. The PEE and total exergy efficiency of ASHPs in heating season are, respectively, $85.68 \%$ and $12.33 \%$, which are close to the PEE and average exergy efficiency of gas furnaces. ASHPs are both sustainable and low-cost equipments for space heating of urban residential buildings in the HSCW zone. 
Table 4. Parameter values of space heating equipments and corresponding calculation results.

\begin{tabular}{|c|c|c|c|c|c|}
\hline & Parameter Values & $\eta(\%)$ & PEE (\%) & $\Psi(\%)$ & SI \\
\hline ASHPs & $\begin{array}{c}\mathrm{HSPF}=2.3 ; T_{1, \text { in }}=6{ }^{\circ} \mathrm{C} ; \\
T_{1, \text { out }}=1.2{ }^{\circ} \mathrm{C} ; \\
T_{2, \text { in }}=18{ }^{\circ} \mathrm{C} ; T_{2, \text { out }}=38{ }^{\circ} \mathrm{C}\end{array}$ & 230 & 85.68 & 12.33 & 1.141 \\
\hline Electric space heating & $T_{N}=18{ }^{\circ} \mathrm{C}$ & 98 & 36.51 & 1.46 & 1.015 \\
\hline \multicolumn{6}{|l|}{ Gas furnaces } \\
\hline With radiators & $T_{S}=75^{\circ} \mathrm{C} ; T_{r}=50^{\circ} \mathrm{C}$ & 80 & 80 & 14.14 & 1.165 \\
\hline With radiant floors & $\mathrm{T}_{S}=45^{\circ} \mathrm{C} ; \mathrm{T}_{r}=38^{\circ} \mathrm{C}$ & 80 & 80 & 9.50 & 1.105 \\
\hline
\end{tabular}

\subsection{Calculation Results for Water Heating and Discussion}

The PEEs, total exergy efficiencies and sustainability indices of various ways of water heating in the 10 cities are shown in Figures 4-6, respectively. The PEEs of storage EWHs and instant EWHs are, respectively, $27.9 \%$ and $33.5 \%$. The total exergy efficiencies of such two types of EWHs are only in the range of $1.2 \%-1.6 \%$, which results in the lowest sustainability indices in Figure 6 . The above results indicate that electric space and water heating are unreasonable ways of energy utilization due to the use of high exergy sources to perform lower exergy tasks. However, EWHs rank first in terms of market share and possession rate in China due to lower prices and convenience [23,24]. From the viewpoint of sustainability, EWHs should be replaced by more sustainable water heating equipment/systems gradually. In Australia, the federal government offers financial packages ranging from $\$ A 1000$ to $\$ A 1600$ for households to replace EWHs with SWHs [27]. In Queensland, the use and sales of EWHs are banned [27].

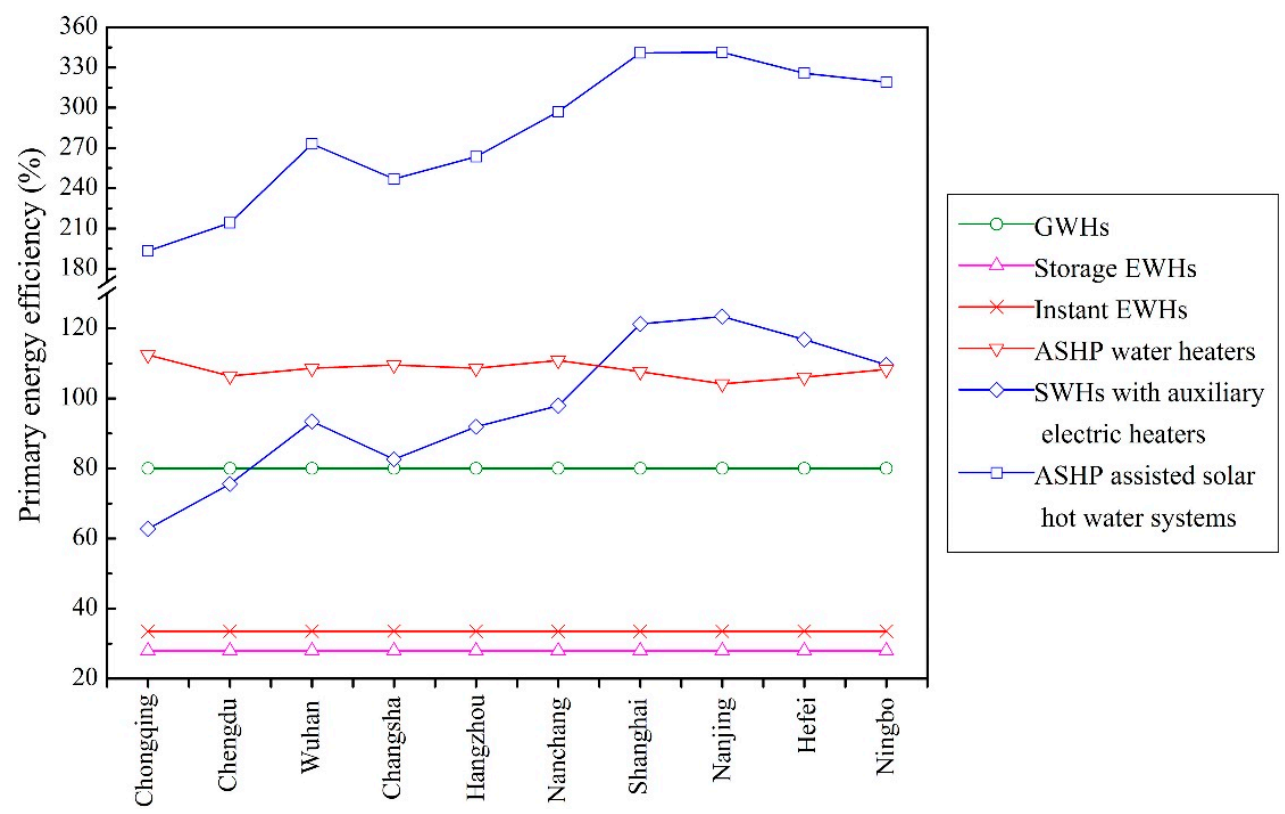

Figure 4. The primary energy efficiencies of various ways of water heating in the 10 cities.

The exergy efficiency of GWHs was found to be in the range of $3.7 \%-4.0 \%$. According to Equations (9) and (11), the improvement of energy efficiency can help to improve the exergy efficiency of GWHs/gas furnaces to some extent. The energy efficiency of the GWHs/gas furnaces with flue gas heat recovery and efficient combustion can be above $90 \%$. On the whole, the direct conversion of high-grade energy (electricity and natural gas) into heat for low exergy requirements (e.g., space heating and heating water to no higher than $45^{\circ} \mathrm{C}$ ) leads to large exergy destructions and low exergy efficiencies. 
The PEEs and total exergy efficiencies of ASHP water heaters in the 10 cities range from $104.2 \%$ to $112.4 \%$ and from $4.8 \%$ to $4.9 \%$, respectively. The climate of these cities in the HSCW zone is generally suitable for the use of ASHP water heaters, which results in a COP ann of between 3.29 and 3.55 (see Table 3). The relatively high COP ann leads to higher PEE and exergy efficiency of ASHP water heaters than those of EWHs and GWHs. The PEE and total exergy efficiency of solar hot water equipment/systems have a lot to do with local solar resources. In the four cities with relative rich solar energy resources (i.e., Shanghai, Nanjing, Hefei and Ningbo), the PEEs and total exergy efficiencies of SWHs with auxiliary electric heaters are all higher than those of ASHP water heaters. In the other six cities with relative poor solar energy resources, the PEEs and total exergy efficiencies of SWHs with auxiliary electric heaters are all lower than those of ASHP water heaters to different degrees, and the PEE values fall below 100\%. Such gaps are rather large in the cases of Chongqing and Chengdu due to poor solar energy resources of the two cities. In the cities with relative poor solar energy resources, the frequent uses of electric heaters for auxiliary heating result in notable decreases of PEE and exergy efficiency. In the other six cities, ASHP water heaters are more suitable for application than SWHs with auxiliary electric heaters.

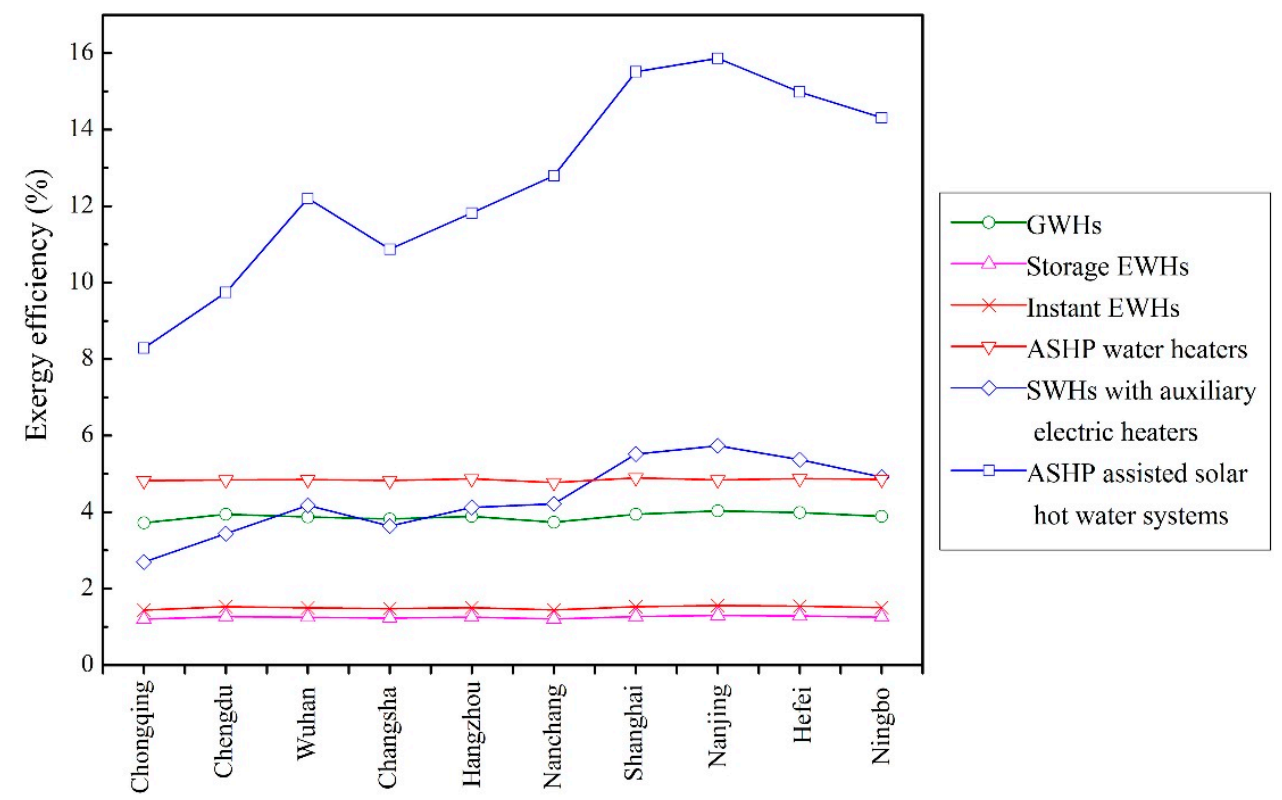

Figure 5. The total exergy efficiencies of various ways of water heating in the 10 cities.

Unlike ASHP water heaters and domestic SWHs, ASHP assisted solar hot water systems can utilize two kinds of renewable energies. The PEEs and total exergy efficiencies of ASHP assisted solar hot water systems in the 10 cities range from $193.2 \%$ to $341.3 \%$ and from $8.3 \%$ to $15.9 \%$, respectively. As can be seen in Figures 4-6, the PEE, exergy efficiency and sustainability indices of such systems are all significantly higher than those of the other water heating equipment. Such results can be mainly attributed to the utilization of renewable heat from solar radiation and the higher energy efficiency of the ASHPs for auxiliary heating (a COP aux of between 2.49 and 2.77) than that of auxiliary electric heaters.

The processes of renewable energy utilization in this study can be illustrated by Grassmann diagrams. Figure 7 shows the schematic of energy flows of the water heating equipment/systems utilizing renewable energy. It can be seen from Figure 7 that the useful heat production is more than the corresponding primary energy input due to the amount of renewable heat that is utilized, which results in a PEE of more than $100 \%$. The utilization of renewable heat for space and water heating in urban residential buildings can bring substantial primary energy savings. 


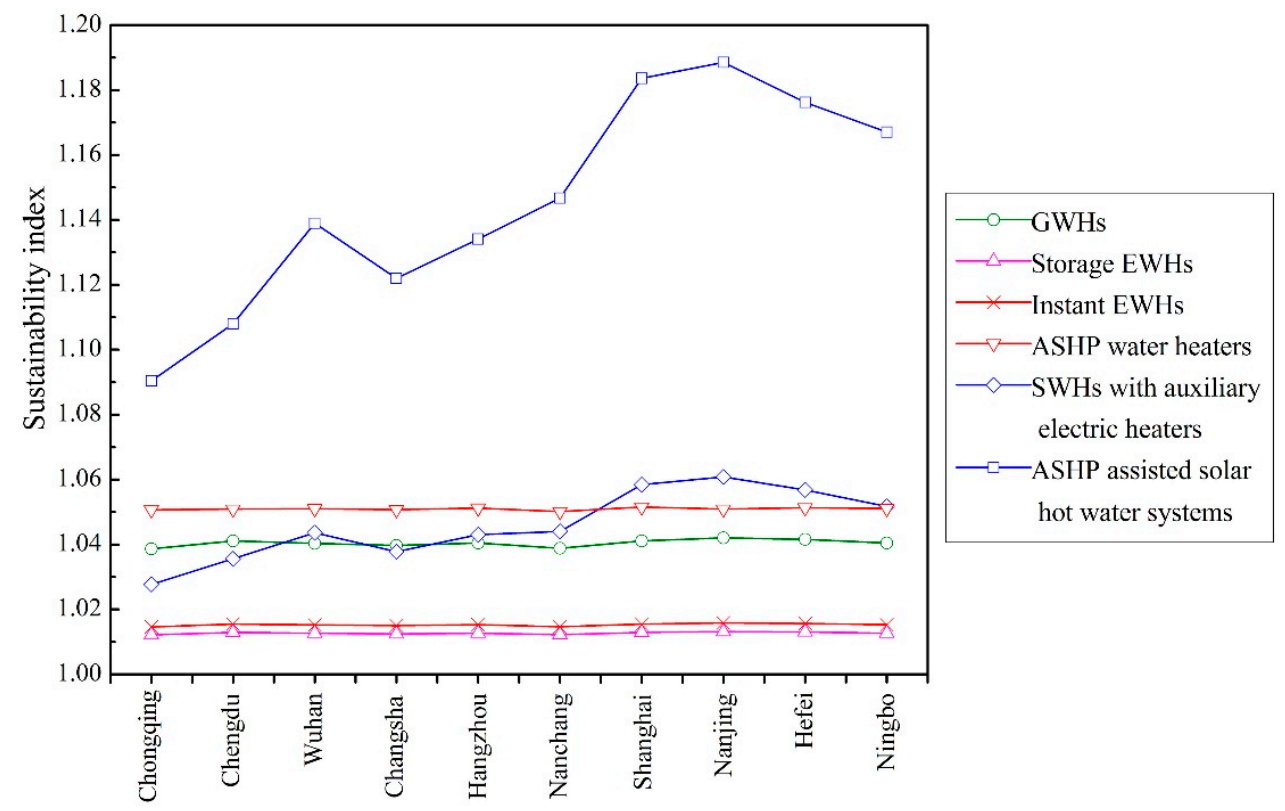

Figure 6. The sustainability indices of various ways of water heating in the 10 cities.

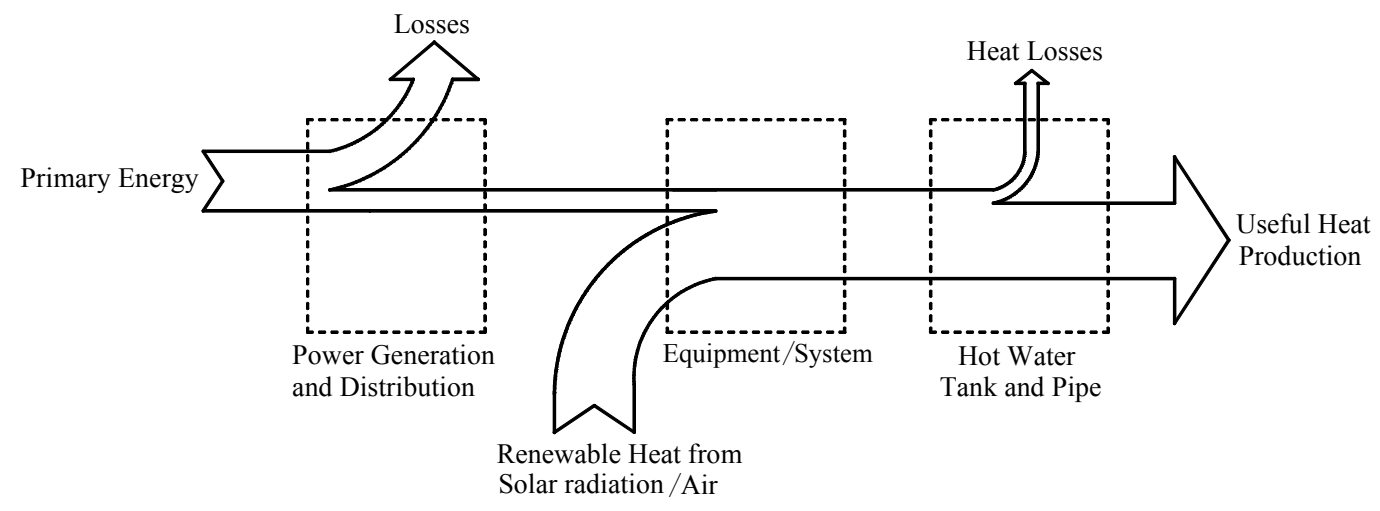

Figure 7. Schematic of energy flows of the water heating equipment/systems utilizing renewable energy.

Figure 8 shows the schematic of exergy flows of solar water heating processes with various auxiliary heating devices. The red dashed lines represent SWHs with auxiliary electric heaters, and the black lines represent ASHP assisted solar hot water systems. The exergy from solar radiation is utilized and contributes much to the exergy production. In terms of the whole energy supply and hot water production system, the largest exergy destructions occur in power generation and distribution, and the second largest exergy destructions occur in auxiliary heating devices and solar collectors. The exergy destructions of auxiliary electric heaters are significantly larger than those of auxiliary ASHPs on the condition that both primary energy inputs and both exergy rates from solar radiation are all equal. As can be seen from Figure 5, the total exergy efficiencies of ASHP assisted solar hot water systems is $5.6 \%-10.1 \%$ higher than those of SWHs with auxiliary electric heaters in the 10 cities. In order to design an energy efficient solar water equipment/system, close attention should be paid to the energy efficiency of auxiliary heating devices and solar collectors. The supply water temperature should be as low as possible to reduce the energy consumption of auxiliary heating and heat losses resulting from hot and cold water mixing at terminals. As for ASHPs, the exergy that can be utilized from ambient air is almost zero. The exergy of electricity is utilized to extract heat from ambient air. 


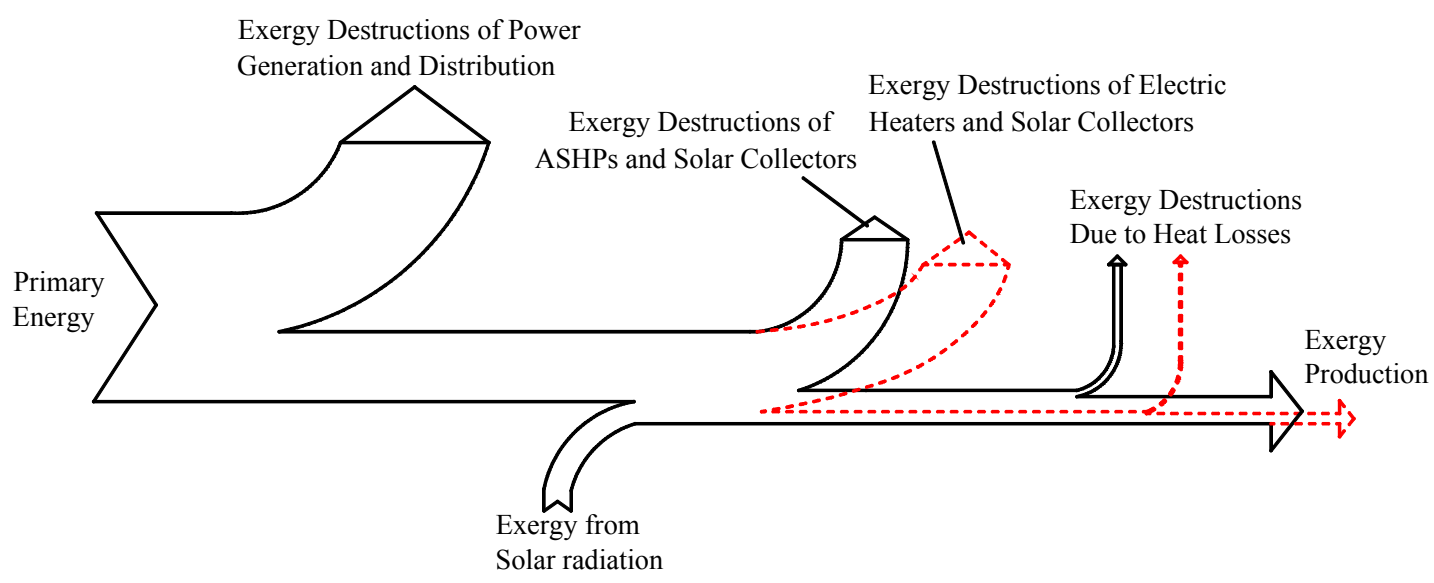

Figure 8. Schematic of exergy flows of solar water heating processes with various auxiliary heating devices.

Though the PEE of ASHP water heaters is higher than 100\% according to above analysis, the market share and the possession rate of ASHP water heaters all were only 3\% in 2014 [23,24]. With the promotion of energy-efficient products from Chinese government, such situations are changing. The sales of ASHP water heaters in 2014 were 31.2\% higher than those in 2013 [23]. The proportion of sales and the possession rate of ASHP water heaters in southern China, including the HSCW zone, are significantly more than those in northern China due to more favorable outdoor temperatures in southern China. From the viewpoint of total exergy efficiency and sustainability index, ASHP assisted solar hot water systems are the most sustainable among all water heating equipment/systems investigated in this study. However, relatively high initial cost has become an obstacle to wide application of such systems. With the subsidies for the applications of renewable energy in buildings from Chinese government, there have been more and more ASHP assisted solar hot water systems in urban residential buildings in recent years.

Based on the above analyses, it is strongly recommended to match the quality levels of energy demand and supply. Space and water heating are low exergy heating requirements, and can be met by solar collectors and ASHPs utilizing low-grade heat from solar radiation and ambient air, respectively. It should be gradually avoided to use electric space and water heating equipment.

\section{Conclusions}

In this study, the PEEs and sustainability indices of various space and water heating equipment/systems in 10 typical cities of the HSCW zone have been evaluated. The energy and exergy flows of the water heating equipment/systems utilizing renewable energy were illustrated. The main conclusions drawn from this study may be summarized as follows:

- The comparison results indicate that electric space and water heating are the most unsustainable ways of space and water heating. There is great potential for improving the quality match between energy supply and demand in urban residential buildings of the HSCW zone. It is suggested that electric space and water heating equipments should be gradually replaced by more sustainable space and water heating equipment/systems.

- The total exergy efficiency of the room air conditioners during heating season was evaluated as $12.33 \%$, and ASHPs are both sustainable and low-cost equipments for space heating of urban residential buildings in the HSCW zone. The PEEs and total exergy efficiencies of ASHP water heaters in the 10 cities were found to range from $104.2 \%$ to $112.4 \%$ and from $4.8 \%$ to $4.9 \%$, respectively. ASHP water heaters are more suitable for application in the cities with relative poor solar energy resources than SWHs with auxiliary electric heaters. 
- The PEEs and total exergy efficiencies of ASHP assisted solar hot water systems in the 10 cities were found to range from $193.2 \%$ to $341.3 \%$ and from $8.3 \%$ to $15.9 \%$, respectively. Due to the utilization of two kinds of renewable energies, ASHP assisted solar hot water systems are the most sustainable among currently used water heating equipment/systems.

The analyses of PEE and exergy efficiency in this study suggest a key potential for improving the energy efficiency and the sustainability of space and water heating in urban residential buildings of the HSCW zone. Besides the utilization of renewable energy and optimized match between energy supply and demand, attention should also be paid to other energy saving strategies. For gas furnaces, GWHs and room air conditioners, it is imperative to improve the utilization efficiency of high-grade energy (i.e., natural gas and electricity). In China, an energy efficiency label system has been established for widely used products with great energy-saving potential. Households should be encouraged to use the products with high energy efficiency grade. Heat recovery from exhaust air and shower water can reduce energy consumption of space heating and water heating, respectively. The heat recovery equipment work by making the fresh air and cold water preheated by exhaust air and drain water, respectively. In view of the fact that there is little application of heat recovery from exhaust air and shower water in residential buildings, such heat recovery equipments can be promoted by integration with air conditioning equipments and unit bathrooms.

Acknowledgments: This work was financially supported by the Hunan Provincial Key Laboratory of Wind Generator and Its Control (No. FLFDYB03), Hunan Institute of Engineering, China and Hunan Provincial Natural Science Foundation of China (12JJ9013).

Author Contributions: Xiao Chen contributed to the conception of this study and the development of its methodology. Yongquan Wen and Nanyang Li performed the measurements and the data analyses. Xiao Chen wrote the manuscript. All authors have read and approved the final manuscript.

Conflicts of Interest: The authors declare no conflict of interest.

\section{References}

1. Berardi, U. A cross-country comparison of the building energy consumptions and their trends. Resour. Conserv. Recyl. 2016. [CrossRef]

2. National Economy and Society Developed Statistical Bulletin 2015. Available online: http:/ /www.stats.gov. cn/tjsj/zxfb/201602/t20160229_1323991.html (accessed on 29 February 2016).

3. Berardi, U. Sustainability assessment in the construction sector: Rating systems and rated buildings. Sustain. Dev. 2012, 20, 411-424. [CrossRef]

4. Kotas, T.J. The Exergy Method of Thermal Plant Analysis; Paragon Publishing: Trowbridge, UK, 1995.

5. Rosen, M.A.; Dincer, I. Exergy analysis of waste emissions. Int. J. Energy Res. 1999, 23, 1153-1163. [CrossRef]

6. Rosen, M.A.; Dincer, I. Thermoeconomic analysis of power plants: An application to a coal-fired electrical generating station. Energy Convers. Manag. 2003, 44, 2743-2761. [CrossRef]

7. Rosen, M.A.; Dincer, I.; Kanoglu, M. Role of exergy in increasing efficiency and sustainability and reducing environmental impact. Energy Policy 2008, 36, 128-137. [CrossRef]

8. Rosen, M.A. Using exergy to correlate energy research investments and efficiencies: Concept and case studies. Entropy 2013, 15, 262-286. [CrossRef]

9. Dincer, I.; Cengel, Y.A. Energy, entropy and exergy concepts and their roles in thermal engineering. Entropy 2001, 3, 116-149. [CrossRef]

10. Hammond, G.P. Industrial energy analysis, thermodynamics and sustainability. Appl. Energy 2007, 84, 675-700. [CrossRef]

11. Cornelissen, R.L. Thermodynamics and Sustainable Development. Ph.D. Thesis, University of Twente, Enschede, The Netherlands, 1997.

12. Utlu, Z.; Hepbasli, A. A Study on the evaluation of energy utilization efficiency in the Turkish residential-commercial sector using energy and exergy analysis. Energy Build. 2003, 35, 1145-1153. [CrossRef]

13. Utlu, Z.; Hepbasli, A. Analysis of energy and exergy use of Turkish residential-commercial sector. Energy Environ. 2005, 40, 641-655. [CrossRef] 
14. Dincer, I.; Hussain, M.M.; Al-Zaharnah, I. Analysis of sectoral energy and exergy use of Saudi Arabia. Int. J. Energy Res. 2004, 28, 205-243. [CrossRef]

15. Al-Ghandoor, A.; Al-Hinti, I.; Akash, B.; Abu-Nada, E. Analysis of energy and exergy use in the Jordanian urban residential sector. Int. J. Exergy 2008, 5, 413-428. [CrossRef]

16. Saidur, R.; Masjuki, H.H.; Jamaluddin, M.Y. An application of energy and exergy analysis in residential sector of Malaysia. Energy Policy 2007, 35, 1050-1063. [CrossRef]

17. Armel, T.K.F.; Vidal, A.K.C.; René, T. Energy analysis and exergy utilization in the residential sector of Cameroon. Energy Power Eng. 2015, 7, 93-104. [CrossRef]

18. Liu, Y.F.; Li, Y.; Wang, D.J. Energy and exergy utilizations of the Chinese urban residential sector. Energy Convers. Manag. 2014, 86, 634-643. [CrossRef]

19. China National Standard. Thermal Design Code for Civil Buildings; GB 50176-93; China Planning Press: Beijing, China, 1993.

20. China Industry Standard. Design Standard for Energy Efficiency of Residential Buildings in Hot Summer and Cold Winter Zone; JGJ 134-2010; China Architecture and Building Press: Beijing, China, 2010.

21. China Meteorological Information Center, Department of Building Science, Tsinghua University. Meteorological Data Sets for Analysis of China Building Thermal Environment; China Architecture and Building Press: Beijing, China, 2005.

22. Building Energy Conservation Research Center, Tsinghua University. Annual Report on China Building Energy Efficiency 2013; China Architecture \& Building Press: Beijing, China, 2013.

23. Bright Future of Heat Pump Water Heaters. Available online: http://rb.n3.com.cn/show.php?itemid=2687 (accessed on 17 February 2016).

24. White Paper on Water Heater Industry in 2014. Available online: http://homea.people.com.cn/n/2014/ 1215/c41390-26211534.html (accessed on 28 February 2016).

25. Stepanov, V.S. Chemical energies and exergies of fuels. Energy 1995, 20, 235-242. [CrossRef]

26. Yang, Y.P.; Yang, Z.P.; Xu, G. Situation and prospect of energy consumption for China's thermal power generation. Proc. Chin. Soc. Electr. Eng. 2013, 33, 1-11. (In Chinese)

27. Li, W.; Rubin, T.H.; Onyina, P.A. Comparing solar water heater popularization policies in China, Israel and Australia: The roles of governments in adopting green innovations. Sustain. Dev. 2013, 21, 634-643. [CrossRef]

(C) 2016 by the authors; licensee MDPI, Basel, Switzerland. This article is an open access article distributed under the terms and conditions of the Creative Commons Attribution (CC-BY) license (http:/ / creativecommons.org/licenses/by/4.0/). 